\title{
Multiple Tooth Agenesis in Non-syndromic Patient: A Rare Case Report
}

\author{
Agenesia Múltiple Dental en un Paciente No-sindrómico: Reporte de un Caso Raro \\ *,**Eduardo Borie; *Ramón Fuentes \& *Víctor Beltrán
}

BORIE, E.; FUENTES, R. \& BELTRAN, V. Multiple tooth agenesis in non-syndromic patient: a rare case report. Int. J. Morphol., 30(2):634-636, 2012.

SUMMARY: Dental agenesis is a term referred to the absence of one or more teeth. However, oligodontia is a severe type of tooth agenesis involving six or more congenitally missing teeth, excluding the third molars. Oligodontia has a low prevalence and is a very rare condition. The aim was to show this case report of a 13-year-old female patient who presented oligodontia with absence of eight permanent teeth and condylar atrophy on left side. The patient had no history of any syndrome or systemic disease according to the anamnesis. Is very important to know oligodontia features to perform a carefully treatment plan.

KEY WORDS: Dental agenesis, Oligodontia, Radiograph.

\section{INTRODUCTION}

Tooth development results of several interactions between oral epithelium and underlying mesenchymatic tissue during odontogenesis (Fuentes \& Oporto, 2009; Borie et al., 2010).

Dental agenesis is a term referred to the absence of one or more tooth and which, in permanent teeth, is a congenital anomaly that is frequently seen in humans (Suda et al., 2011). The overall prevalence of agenesis ranges from $1.4 \%$ to $11.3 \%$ in different regions and populations (Sisman et al., 2007; Shimizu \& Maeda, 2009; Aktan et al., 2010). On the other hand, oligodontia is a severe type of tooth agenesis involving six or more congenitally missing teeth, excluding the third molars (Shimizu \& Maeda; Wang et al., 2011). The prevalence for oligodontia is in ranges of $0.03 \%$ to $0.07 \%$ (Celikoglu et al., 2010; Aktan et al.). Oligodontia is a very rare condition (Rolling \& Poulsen, 2001).

The etiology of tooth agenesis is still largely unknown (Goodman et al., 1994). Dental agenesis may be caused by factors related either to the mucosal ectoderm, to the ectomesenchyme, or to innervation (Kjær et al., 1994). Also, in people with agenesis of a single tooth, it was considered more likely by a local factor in the region (Kjær et al., 2008). Amongst all non-syndromic (familial or sporadic) agenesis conditions detected in humans, the most common is the absence of third molar(s) with an average about 20\% (PaixãoCôrtes et al., 2011). Some studies have reported that mutations in the homeobox gene MSX1, paired domain transcription factor PAX9, and EDA are associated with nonsyndromic oligodontia (Swinnen et al., 2008; Suda et al.; Paixão-Côrtes et al.). Renault (1990) mentioned that cases with agenesis in maxilla and mandible and with and absence of nine or more teeth need a very complex dental treatment. Some authors as Vinay et al. (2011) reported a case with oligodontia related with osteopetrosis, which is a rare hereditary disorder of the skeleton characterized by increased density of the bones.

Tooth agenesis is more reported in females than in males (Mattheeuws et al., 2004; Celikoglu et al.) and more found in maxilla than the mandible with a similar number of missed teeth in both sides (Aktan et al.). The most frequently missing teeth were the maxillary lateral incisors, followed by the mandibular second premolars and the mandibular central incisors (Celikoglu et al.). Is important to point out that agenesis of maxillary central incisors, canines, and first permanent molars reportedly is very rare (Tavajohi-Kermani et al., 2002). The absence of permanent teeth may cause some several clinical problems, such as malocclusion making orthodontic treatment difficult and requiring orthognathic surgery (Mattheeuws et al.).

\footnotetext{
"Departamento de Odontología Integral, Universidad de la Frontera, Temuco, Chile.

** Post-Graduate Student, Department of Dental Materials and Prosthodontics, Dental School of Ribeirão Preto, University of São Paulo, Ribeirão Preto, SP, Brazil.
} 


\section{CASE REPORT}

A 13-year-old female patient came in May 2011 to the Dental Clinics of the Universidad de La Frontera (Temuco, Chile) reporting absence of some teeth. Through a digital panoramic radiograph the existence of multiple agenesis of permanent dentition was revealed. In the radiograph agenesis of tooth $1.4,1.5,1.7,2.5,2.7,3.4,3.5,4.5$ (Fig. 1) was identified, with a small dimension of maxilla. Also, a slight condylar asymmetry with a small size and a slight stylohyoid ligament ossification was noted in the left side. After this, a foot radiograph was taken to determine if the condition had a relation with an osteopetrosis; however, normal findings were noted. During anamnesis the patient reported she had no trauma history, previous tooth extraction, orthodontic treatment or complications during pregnancy or birth. The patient's mother informed that there was no history of syndromic or systemic disease.

At general examination no alterations or systemic diseases were identified, with facial symmetry, no palpable lymph nodes and both jaws were normal. Clinically, in the intraoral examination no caries and the absence of the same teeth were observed with tooth rotation of 1.3, 2.3 and 4.3. No presence of periodontal disease was noted.

\section{DISCUSSION}

Dental anomalies can results from many factors, including genetic and environmental ones. Although defects in certain genes have the highest incidence, etiological events in prenatal and postnatal periods have also been blamed for anomalies in tooth number, dimension, morphology, position, and structure (Basdra et al., 2000; Uslu et al., 2009). In this case report, the patient presented oligodontia because it had absence of eight teeth excluding third molars. The predominance in females was according with the stated with Mattheeuws et al. Also, this case concurs with Aktan et al. who reported that similar number of missed teeth was in both sides and maxilla was more affected. Celikoglu et al. found that the most frequently missing teeth were the maxillary lateral incisors, followed by the mandibular second premolars and the mandibular central incisors; however, in this case only second premolars agrees with the previously raised. The other teeth compromised were not reported in the literature. Some authors had found a relation between oligodontia and osteopetrosis (Vinay et al.); however, this hypothesis was discarded when foot radiograph density was observed.

In the present case, the alveolar process was affected which concurs with Tavajohi-Kermani et al. The absence of eight permanent teeth causes some several clinical problems with the dimension of maxilla and mandible. The above, was supported by Mattheeuws et al. The small size in maxilla concurs with Bu et al. (2008) who found a smaller dimension in patients with oligodontia. All this leads to a very complex dental treatment, agreeing with Renault. Patient's history and anamnesis concurs with a non-syndromic patient.

Finally, is very important to know oligodontia features to perform a carefully treatment plan.

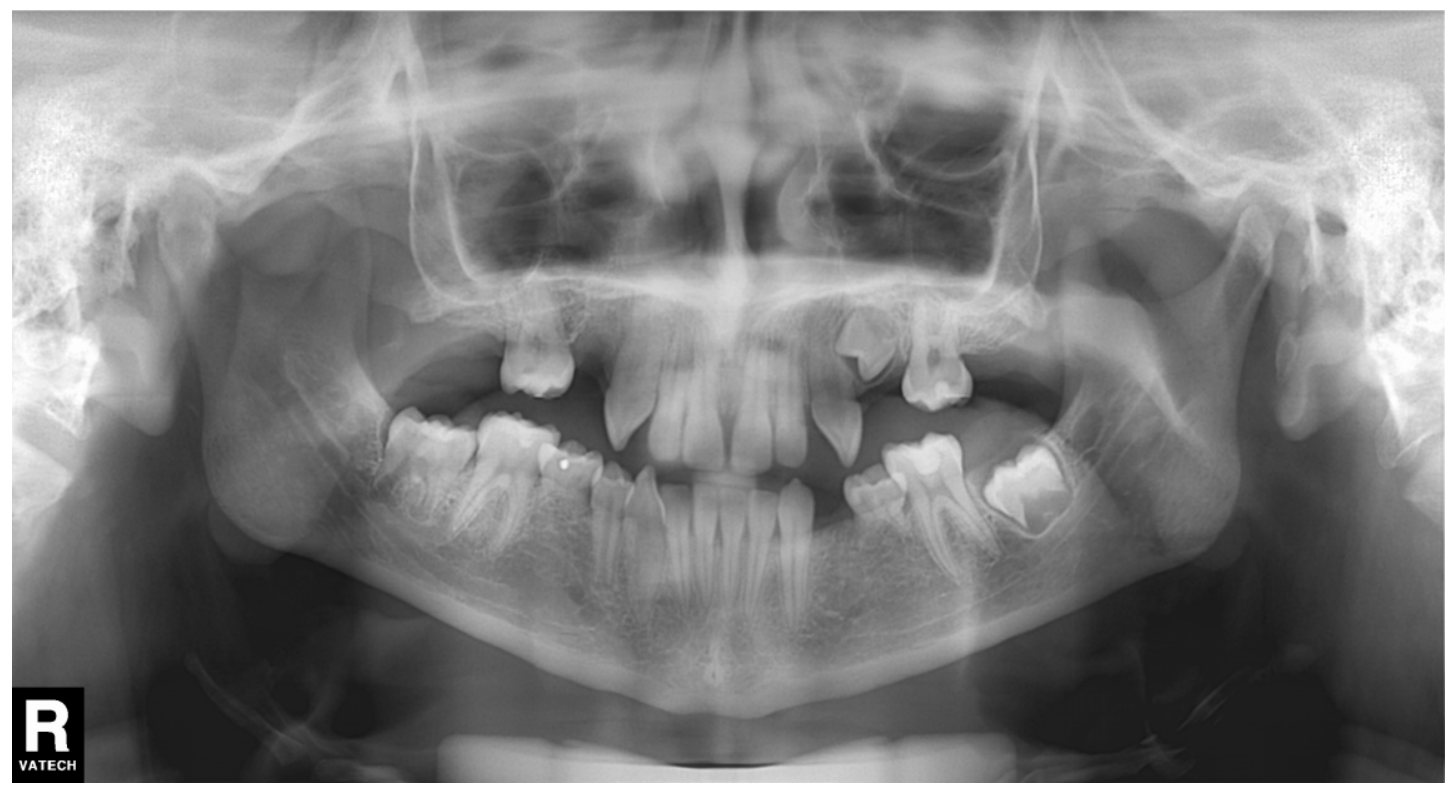

Fig. 1. Panoramic radiograph of the patient. Note the absense of eight teeth and the small dimension in maxilla. 
BORIE, E.; FUENTES, R. \& BELTRAN, V. Agenesia múltiple dental en un paciente no-sindrómico: reporte de un caso raro. Int. J. Morphol., 30(2):634-636, 2012.

RESUMEN: La agenesia dental es un término que se refiere a la ausencia de uno o más dientes. Sin embargo, la oligodoncia es un tipo grave de agenesia dental con ausencia congénita de seis o más dientes, excluyendo los terceros molares. La oligodoncia tiene una prevalencia baja y es una condición muy rara. El objetivo es presentar este reporte de caso de una paciente femenina de 13 años quien presentó oligodoncia con ausencia de ocho dientes permanentes y atrofia condilar en el lado izquierdo. La paciente no presenta historia de padecer algún síndrome o enfermedad sistémica según su anamnesis. Es muy importante de conocer las características de la oligodoncia para llevar a cabo un plan de tratamiento de manera cuidadosa.

PALABRAS CLAVE: Agenesia dental, Oligodoncia, Radiografía.

\section{REFERENCES}

Aktan, A. M.; Kara, I. M.; S, ener, I.; Bereket, C.; Ay, S. \& Çiftçi, M. E. Radiographic study of tooth agenesis in the Turkish population. Oral Radiol., 26(2):95-100, 2010.

Basdra, E. K.; Kiokpasoglou, M. \& Stellzig, A. The class II division 2 craniofacial type is associated with numerous congenital tooth anomalies. Eur. J. Orthod., 22:529-35, 2000.

Borie, E.; Oporto, G. \& Aracena, D. Dens Evaginatus in Hemophilic Patient: a case report. Int. J. Morphol., 28:375-8, 2010.

Bu, X.; Khalaf, K. \& Hobson, R. S. Dental arch dimensions in oligodontia patients. Am. J. Orthod. Dentofacial Orthop., 134(6):768-2, 2008.

Celikoglu, M.; Kazanci, F.; Miloglu, O.; Oztek, O.; Kamak, H. \& Ceylan, I. Frequency and characteristics of tooth agenesis among an orthodontic patient population. Med. Oral Patol. Oral Cir. Bucal, 15(5):797-801, 2010.

Fuentes, R. \& Oporto, G. Ectopic and impacted third molar in retromolar zone. A Case Report. Int. J. Morphol., 27: 35-8, 2009.

Goodman, J. R.; Jones, S. P.; Hobkirk, J. A. \& King, P. A. Hypodontia: 1.Clinical features and the manageent of mild to moderate hypodontia. Dent. Update, 21:381-4, 1994.

Kjær, I.; Kocsis, G.; Nodal, M. \& Christensen, L. R. Aetiological aspects of mandibular tooth agenesis - focusing on the role of nerve, oral mucosa and supporting tissue. Eur. J. Orthod., 16:3715,1994 .

Kjær, I.; Nielsen, M. H. \& Skovgaard, L. T. Can persistence of primary molars be predicted in subjects with multiple tooth agenesis? Eur. J. Orthod., 30(3):249-53, 2008.

Mattheeuws, N.; Dermaut, L. \& Martens G. Has hypodontia increased in Caucasians during the 20th century? A meta-analysis. Eur. J. Orthod., 26(1):99-103, 2004.

Paixão-Côrtes, V. R.; Braga, T.; Salzano, F. M.; Mundstock, K.; Mundstock, C. A. \& Bortolini, M. C. PAX9 and MSX1 transcription factor genes in non-syndromic dental agenesis. Arch. Oral Biol., 56(4):337-44, 2011.
Renault, P. Multiple agenesis and prosthetic restoration. Cah. Prothese, 69:60-71, 1990.

Rolling, S. \& Poulsen, S. Oligodontia in Danish schoolchildren. Acta Odontol. Scand., 59(2):111-2, 2001.

Shimizu, T. \& Maeda, T. Prevalence and genetic basis of tooth agenesis. Jpn. Dent. Sci. Rev., 45(1):52-8. 2009.

Sisman, Y.; Uysal, T. \& Gelgor, I. E. Hypodontia. Does the prevalence and distribution pattern differ in orthodontic patients?. Eur. J. Dent., 1(3):167-73, 2007.

Suda, N.; Ogawa, T.; Kojima, T.; Saito, C. \& Moriyama, K. Nonsyndromic oligodontia with a novel mutation of PAX9. J. Dent. Res., 90(3):382-6, 2011.

Swinnen, S.; Bailleul-Forestier, I.; Arte, S.; Nieminen, P.; Devriendt, K. \& Carels, C. Investigating the etiology of multiple tooth agenesis in three sisters with severe oligodontia. Orthod. Craniofac. Res., 11(1):24-31, 2008.

Tavajohi-Kermani, H.; Kapur, R. \& Sciotte, J. J. Tooth agenesis and craniofacial morphology in an orthodontic population. Am. J. Orthod. Dentofacial Orthop., 122(1):39-47, 2002.

Uslu, O.; Akcam, M. O.; Evirgen, S. \& Cebeci, I. Prevalence of dental anomalies in various malocclusions. Am. J. Orthod. Dentofacial. Orthop., 135:328-35, 2009.

Vinay, C.; Uloopi, K.S.; Rao, R. C.; Kumar, R. S. \& Madhuri, V. Oligodontia associated with osteopetrosis: a rare case report. $J$. Dent. Child., 78(1):53-6, 2011.

Wang, J.; Jian, F.; Chen, J.; Wang, H.; Lin, Y.; Yang, Z.; Pan, X. \& Lai, W. Sequence analysis of PAX9, MSX1 and AXIN2 genes in a Chinese oligodontia family. Arch. Oral. Biol., 56(10):102734. 2011.

Correspondence to:

Eduardo Borie Echevarría

Departamento Odontología Integral

Facultad de Medicina

Universidad de la Frontera

Manuel Montt 112

Received: 01-12-2011

Temuco - CHILE

Accepted: 22-02-2012

E-mail: eduardoborie@ufro.cl 